\title{
E-Campaigning in the 2014 European Elections:
}

\section{The emphasis on valence issues in a two-dimensional multi-party system}

\author{
Andrea Ceron \\ Assistant Professor \\ Università degli Studi di Milano, Dept. of Social and Political Sciences \\ Via Conservatorio, 7 - 20122 Milano (Italy) \\ andrea.ceron@unimi.it \\ Luigi Curini (Corresponding Author) \\ Associate Professor \\ Università degli Studi di Milano, Dept. of Social and Political Sciences \\ Via Conservatorio, 7 - 20122 Milano (Italy) \\ luigi.curini@unimi.it \\ Tel. +390250321231 \\ Fax +390250321240
}

Andrea Ceron is assistant professor in Political Science at the Department of Social and Political Sciences, Università degli Studi di Milano, Milan. His research focuses on intra-party politics, quantitative text analysis, social media and political trust.

Luigi Curini is associate professor in Political Science at the Department of social and political sciences, Università degli Studi di Milano and visiting professor at Waseda University, Tokyo. His main research interests focus on spatial theory of voting, electoral competition, legislative behaviour, quantitative methods, social media analysis. 


\section{E-Campaigning in the 2014 European Elections:}

\section{The emphasis on valence issues in a two-dimensional multi-party system}

During electoral campaigns, political parties have to decide how to allocate resources choosing between alternative campaign strategies that allow them to fulfill their goals. Besides competing on the basis of their policy platforms, parties and candidates can also take advantage of valence issues to increase their votes share. Recent studies have shown that valence competition impinges on a party's electoral fortune (e.g., Abney et al., 2013; Meirowitz, 2008; Schofield, 2003; Zakharov, 2009). In this respect, scholars have started to investigate the determinants of valence competition focusing on party incentives (Serra, 2010; Damore, 2002; Ashworth and Bueno de Mesquita, 2009; Skapersdas and Grofman, 1995; Theilmann and Wilhite, 1998; ElmelundPræstekær, 2008). In this regard, a growing branch of the literature paid attention to how the ideological distance between parties affects their propensity to revert to valence strategies (Green, 2007; Curini and Martelli, 2010; Curini, 2015; Walter, 2014; Walter et al., 2014).

Most of these studies (with some noteworthy exceptions, e.g. Schofield and Sened, 2006; Ansolabehere and Snyder, 2000) assume that the policy space where party competition occurs is one-dimensional. This choice is coherent with the actual shape of electoral campaigns in many political systems (Cox, 1990; McDonald and Budge, 2005; Budge et al., 2001). Even so, we can find examples of electoral campaigns fought on more than one policy dimension (see Benoit and Laver, 2006; Laver and Schofield, 1990). For instance, during European election campaign parties traditionally divide themselves not only along the traditional left-right scale, but they also compete on a second policy dimension, which distinguishes those in favor or against further and deeper European integration (Hix et al., 2007). 
Following on this, in the present paper we will first explore the relationship between spatial proximity and the incentives of parties to highlight valence issues in a two-dimensional world, while distinguishing also the tone (positive or negative) of such valence campaigning and the theoretical consequences of that. Our hypotheses will be then tested by analyzing the electoral strategies of parties belonging to the five largest European democracies (i.e., France, Germany, Italy, Spain and the United Kingdom), during the recent 2014 European Elections. To do that, we selected all the messages published on the official Twitter account of each party when the attention toward the campaign was at its peak, i.e. in the last week before the election-day. Our empirical analysis, based on an expert survey held before the campaign, provides support for the relationship between spatial proximity and the incentives of political parties to perform valence campaigning (measured as the share of 'valence tweets' published online by a party). Moreover, our findings confirm the importance of distinguishing the tone of valence messages to better understand how the spatial distance between parties impinges on their incentives to adopt a valence campaigning.

The paper is organized as follows. Section one discusses the theoretical implication of valence campaigning in a two-dimensional multi-party system raising two main hypotheses. Section two describes the data collection process. Section three displays the results. A conclusion follows.

\section{Ideological distance and valence campaigning in two dimensions}

Let us consider a two-dimensional ideological space in which parties compete to win the support of voters. We assume that voters cast their vote sincerely based on decreasing squared utility functions that are identically spaced from their ideal points - an hypothesis commonly done in most of the literature on spatial voting (Calvo and Hellwig, 2011; Adams et al., 2005) that implies that voters are risk-averse (i.e., that voters place progressively greater weight on objects, that is, on parties' programs, that are farther apart). Moreover, let's assume for sake of simplicity that voters' ideal points are evenly distributed on the two-dimensional ideological space. 
Figure 1 below draws a spatial representation of such space with respect to the European election campaign in Italy. It reports the location of the main parties that contested the election (see the next section for details on the method employed to estimate party positions), along with a Voronoi diagram. This diagram is an exclusive and exhaustive partition of the space into regions so that each region is associated with a unique generating point and any point in the region is closer to the region's generating point than to any other generating point (Laver and Hunt, 1992; Benoit and Laver, 2006; Laver and Sergenti, 2012). In our case, the generating points are the policy position of each party and the set of points in each region are voters ideal points. Any voter's ideal point in a given region is by definition closer to the policy position of the party associated with that region's generating point than to any other party. Therefore, in a pure Downsian world (i.e., in a world where voters care only about the policy package offered by parties), each party's region contains voters that (spatially) support the party located in that area. So, for example, in Figure 1 voter $i$ will vote for PD and voter $j$ for M5S.

\section{Figure 1 here}

Policy positions, however, are not the only element affecting the vote choice. As is well know, in fact, voters also evaluate the political offer in terms of 'valence issues' (e.g., Stokes 1963). Valence issues can be policy-based, i.e. related to "issue ownership" (Budge and Farlie, 1983), or non-policy-based (Adams et al., 2011; Stone and Simas, 2010). Here we focus on the latter (e.g., trustworthiness, credibility, honesty, competence), which are unrelated with policy positions and hence more in line with our theoretical framework (see below). Irrespective of this distinction, however, while voters retain different and conflicting views on policy issues (e.g., welfare state, gay marriage, etc.), they hold identical preferences on valence issues. As such, parties that prevail on the latter issues do retain an electoral advantage independent of their policy positions (for a discussion: Clark, 2013).

Following a common notation (Groseclose, 2001), the utility of the generic voter with ideal point $i$ to vote for party $J$ is represented as follows: 


$$
\mathrm{U}_{\mathrm{iJ}}=\mathrm{V}_{\mathrm{J}}-\mathrm{d}(\mathrm{i}, \mathrm{J})^{2},(1)
$$

where $\mathrm{V}_{\mathrm{J}}$ is the valence endowment of party $J$, and $\mathrm{d}(\mathrm{i}, \mathrm{J})^{2}$ is the squared Euclidean distance between $i$ and $J{ }^{1}$ The key implication of (1) is that the utility gain due to higher valence may outweigh the utility loss related to a greater policy distance (Laver and Sergenti, 2012). As a consequence, a voter may get a higher utility when voting for a party that prevails on valence issues even though this party is located away from the voter's ideal point than when voting for a closer party with a lower valence. In particular, voter $i$ prefers a higher valence party $K$ to a lower valence party $J$, despite the fact that $J$ is closer to $i$, if:

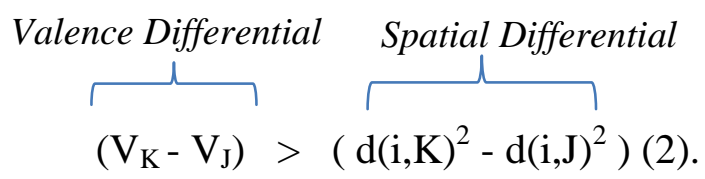

In other words, voter $i$ prefers the more distant party $K$ if the valence differential between the parties (the term on the left-side of the inequality) exceeds the difference in their quadratic distances from voter $i$ 's ideal point, i.e., the 'spatial differential' among parties (the term on the right-side of the inequality). From (2) we can derive that any valence differential is more important in affecting $i$ 's vote choice the more the spatial differential decreases. In particular, any valence differential is disproportionally more effective the more party $K$ and $J$ present a similar policy position (because the effects of policy distance in (1) and (2) are quadratic). Conversely, when party $K$ and $J$ retain very different policy positions, even an hypothetically huge valence differential in

\footnotetext{
${ }^{1}$ According to (1), we express valence and policy loss on the same metric (this involves no loss of generality). Following Laver and Sergenti (2012) and Adams et al. (2005) we also assume that, in addition to being known to voters, the valence endowments of both parties are valued equally by all (for a different perspective in this regard, see Zakharova and Warwick 2014, Shikano and Käppner 2014).
} 
favor of party $K$ might not be sufficient to convince voter $i$ to vote for party $K$ if such valence differential does not overcome the spatial differential.

Let's go back now to explain how ideological positions and electoral considerations can affect the decision of parties to adopt a campaign based on valence issues. Leaving aside situations in which parties can change their location, ${ }^{2}$ we provide a straightforward theoretical decisionmaking model that produces clear hypotheses that will be empirically tested.

Let us assume that party $K$ can purposely undertake a valence campaign, either positive (aimed to increase its own valence endowment) or negative (aimed to decrease the valence endowment of the competing party). ${ }^{3}$ We first consider a two-party system, like the United States. Figure 2 displays a space with two different policy dimensions (economic on the horizontal axis and foreign affairs on the vertical axis) in which competition takes place between two parties, $J$ and $K$, and sketches two simulated scenarios. In both situations party $J$ is closer to voter $i$ than party $K$.

In the left panel, Party $J$ is located at point $(3,6)$; party $K$ at point $(8,10)$, and voter $i$ at point $(5,8)$. In the right panel, party $K$ and voter $i$ keep their position while Party $J$ is now located at point $(7.5,9.5)$. Let's further assume that in both panels party $K$ enjoys a simulated valence advantage equal to $\left(\mathrm{V}_{\mathrm{K}^{-}} \mathrm{V}_{\mathrm{J}}\right)=4.6$. Therefore, the only difference between these two scenarios is that party $J$ is closer to party $K$ in the right panel. The solid lines represent the Voronoi diagrams built by considering only policy issues in the utility function of voters (i.e., equation (1) sans the $\mathrm{V}_{\mathrm{J}}$ term), while the dashed line identifies the Voronoi diagrams measured by considering also valence

\footnotetext{
${ }^{2}$ For game theoretical models applied to two-party systems that allow parties to modify their policy platforms on one dimension see, for instance, Ashworth and Bueno de Mesquita (2009) and Serra (2010).

${ }^{3}$ On the role played by negative campaigning in political competition see: Hansen and Pedersen (2008); Skaperdas and Grofman (1995).
} 
issues (i.e., equation (1) with the $\mathrm{V}_{\mathrm{J}}$ term included). ${ }^{4}$ By looking at the two Voronoi diagrams portrayed in each panel, we can see that in the left panel voter $i$ will vote for party $J$ (the closer party) no matter whether we consider valence issues or not. Moreover, the amount of votes that party $K$ is able to gain thanks to its valence advantage is rather limited. Conversely, in the right panel, voter $i$ will be willing to vote for the farther party $K$ when we take valence issues into account. In this scenario, $K$ is now able to gain a larger share of votes from party $J$ (compared with the previous case). While the valence differential remains the same, it becomes more "effective" in terms of luring voters due to spatial reasons because now party $K$ and $J$ are closer to each other.

\section{Figure 2 here}

In this example, it does not matter whether the valence advantage of party $K$ is the product of a positive valence campaigning that increases its valence value (i.e., $\mathrm{V}_{\mathrm{K}}$ ) or the result of a negative valence campaigning that decreases the valence value of party $J$ (i.e., $\mathrm{V}_{\mathrm{J}}$ ). Either way, party $K$ thanks to such valence campaigning will gain the same amount of votes according to the distance between its position and that of party $J .^{5}$ Things, however, can be different as we will see.

Moving from a two-party system (as in the previous example) to a multi-party system (which is a feature typical of European countries) raises two implications. The first one applies irrespective to the number of the dimensions of the policy space (on this point see also Curini 2015;

\footnotetext{
${ }^{4}$ More formally, the dashed line in both panels of Figure 2 identifies two additively weighted power Voronoi diagrams (see Laver and Sergenti 2012; Okabe et al. 2000).

${ }^{5}$ We are not considering here the cost of valence campaigning (financial and human resources). However, modeling such cost does not alter our argument given that any party will allocate (scarce) resources to valence campaigning only when the expected benefit is significant. When two parties are ideologically distant a valence-based campaign will require too many investments and each party will rather spend its limited resources in a policy-based campaigning.
} 
Curini and Martelli 2015). Let us call neighbors those parties with contiguous cells in the Voronoi decompositions of the policy spaces. ${ }^{6}$

Then, in a multi-party system a party should not be affected by the spatial positions of nonneighbors, given that by investing in valence campaigning it can spatially lure out only the voters of its neighbors. Consider, for instance, the case of the Tsipras List (The other Europe with Tsipras) in Figure 1: we would expect that its incentive to enact valence campaigning increases as its neighbors (either PD or M5S or both) are located closer to its spatial position, given that in this case even a small valence differential becomes electoral rewarding (remember the previous example). As a consequence, the incentive for the Tsipras List to compete on valence is very strong when both its neighbors are close to it (given that in this case it can gain a relatively larger amount of voters from both parties), moderately strong if at least one of the two neighbors party is close, and the incentive rapidly declines when both neighbors are far away. On the contrary, what happens to the spatial position of non-neighbors (such as New Center-Right (NCD) in Figure 1) should not be of any impact per-se on such incentives. Note that this last assertion holds true under the reasonable assumption that the valence campaign of a party (e.g., the Tsipras List) cannot be so effective as to complete annihilate the electoral support of the Democratic Party (PD) and Five Stars Movement (M5S), i.e., the neighbor parties of the Tsipras List. If that was the case, in fact, the Tsipras List valence superiority would also impinge on the votes share of its non-adjacent parties (NCD, Northern League and Scelta EU), making as a consequence the spatial incentives of the Tsipras List to invest in valence campaign to be affected by the position of those latter parties as well. We consider this latter scenario (i.e., a situation in which a party is able to completely absorb the vote share of some of its neighbors) as quite unrealistic, at least under normal political circumstances. This brings us to the following first hypothesis according to our theoretical argument:

\footnotetext{
${ }^{6}$ On the role of spatial contiguity in affecting the strategy of parties see also Williams (2015).
} 
H1: In a two-dimensional multi-party system the incentive of a party to campaign on valence issues grows when the distance between it and its neighbors decreases.

The second implication of valence campaigning in a multi-party system is specific to the two-dimensional space scenario. In a one-dimensional ideological space a party can have either one neighbor (if that party is located on the extreme left or right) or at most two neighbors (if it is not located on the extreme). Conversely, in a two-dimensional policy space, a party can have (and usually has) several neighbors. For instance, in our case the average number of neighbors per party is 3.1 (standard deviation: 1.1) and no party has only one neighbor (see below). That is, we should always find a higher number of neighbors in a two-dimensional space rather than in a onedimensional space, irrespective of the total number of parties in the party system (as long as we are dealing with a multi-party system).

This rather obvious geometrical result has a non-obvious implication on what discussed up to now. By investing in positive valence campaigning, a party can in fact potentially gain the votes of all its neighbors. Therefore, the higher the number of neighbors, the higher the incentive to invest in valence campaigning produced by ideological considerations. On the contrary, by investing in negative valence campaigning a typical collective action problem arises, given that a party risks to not internalize all the possible electoral benefits deriving from it. For instance, Tsipras party knows that any successful negative attack aimed to decrease the valence endowment of PD (and/or M5S), would also benefit each of the (quite numerous) neighbors of such party (see Figure 1), given that all the neighbors of PD would gain some share of voters in case the latter party decreases its valence endowment for the reasons previously discussed. Precisely for that, we can also anticipate that a decrease in the distance separating a party from its neighbors (i.e., its spatial incentive) should be more effective in producing a positive campaign on valence issues rather than a negative one. This produces our second hypothesis: 
H2: In a two-dimensional multi-party system, the spatial incentive of a party to campaign on positive valence issues should be stronger than the incentive to campaign on negative valence issues.

\section{Data collection and operationalization}

To empirically test the previous hypotheses, we analyse the 2014 European elections. European elections are traditionally considered second-order elections (Hix and Marsh, 2011; Reif and Schmitt, 1980) in comparison to the more important national ones. The 2014 European elections, however, seem to be the first 'truly' European competition as parties also emphasized policy struggles that took place at the supra-national European level albeit modeled in a domestic perspective.

For our purposes, we analyse the content of online electoral campaign in the five largest Western European countries: France, Germany, Italy, Spain and the United Kingdom. These five countries account for a variety of different political contexts. In 2014, in fact, two of them were ruled by centre-right parties (Spain and UK), two by centre-left parties (France and Italy) and one by a 'Grosse coalition' involving the main centre-right and centre-left party (Germany); moreover in three of these party systems (France, Italy and UK) we found strong Euro-sceptic parties, while in the remaining two (Germany and Spain) Euro-sceptics only represented a minority of voters. In addition, these countries cover three different models of media systems (Hallin and Mancini 2004), i.e. the polarized pluralist model (France, Italy and Spain), the corporatist model (Germany), and the liberal one (UK).

We take advantage of the fact that, nowadays, political parties tend to broadcast the whole electoral campaign on their social media accounts, to amplify the statements made by party leaders and candidates during party rallies or television debates (Ceron and D'Adda, 2013; Elmer, 2013). Several scholars support the 'normalization thesis' and argue that there is no difference between the political parties' usage of the web or traditional media (Druckman et al., 2010; Vergeer and Hermans, 2013). For instance, Vergeer et al. (2013) analyze the usage of Twitter made by 
candidates running for the European Parliament in 2009 showing that, rather than developing personalized and targeted messages, their tweets were in line with the party's official campaign even in contexts where intra-party competition should provide candidates with the incentive to enact tailored e-campaigns (Vergeer et al., 2013: 496). As such, Internet becomes 'nothing more than an extended tool to distribute the same information used in offline campaigning' (Vergeer et al., 2013: 482).

In this regard, Twitter plays a prominent role. Given that parties tend to broadcast on Twitter the statements made by their leaders during rallies, interviews, or television debates, the analysis of parties' official Twitter accounts allows to describe the overall dynamics of the campaign (both online and off-line) and provides intriguing insights on the party strategy to enact purposeful valence campaigning (Ceron and d'Adda, 2015). Accordingly, we collected all the electoral campaigning messages posted on the official Twitter accounts of national parties in the last week before the election-day using the Twitter API.

We focused on the last week for two main reasons. First, in the very short term (namely few days before the election) it is unlikely that parties decide to change their position, either because election manifestos have already been published or because any last-minute variation in the overall ideological platform of a party can increase uncertainty and ambiguity damaging the party. ${ }^{7}$ Therefore, we can control for any variation related to a shift in the policy position of a party, coherently with our model. Second, we can analyze the party strategy when the electoral campaign reaches its peak and campaign messages can eventually produce shifts in the voting intention that persist until the election day (Enns and Richman, 2013; Wlezien and Erikson, 2002).

\footnotetext{
${ }^{7}$ Indeed, a clear party label and a clear platform have a positive effect on a party's electoral performance (McGann, 2002; Snyder and Ting, 2002).
} 
The total number of tweets downloaded amounts to 12,461 , with a mean of almost 378 tweets per party. ${ }^{8}$ These tweets have been manually codified to assess whether they expressed valence campaigning or not. According to the already stressed attention to non-policy-based valence issues, tweets have been classified in three different categories: "Negative valence campaigning" (NVC), when they contained attacks against a rival party on similar issues; "Positive valence campaigning" (PVC), when they emphasized partisan qualities (e.g., honesty, competence, etc.); “Others”, which accounts for all the residual tweets (i.e., tweets reporting news or discussing explicitly about policy issues for example).

Per each country, we report here some examples of tweets written to express positive or negative campaigning on valence issues. For instance, "Vote for our honest candidates that are going to work hard" is a tweet written by the French Greens to perform positive campaigning on valence issue as it highlights the positive qualities (honesty and commitment) of the Greens' candidates. Analogously, "Our party thinks to the general interest of the country before that of the party itself \#VotePP" suggests that the Spanish Popular Party is not a selfish one; the tweet "On the ballot paper vote honesty, quality and competence: vote@forza_italia”highlights the valence qualities of the Forza Italia party, exactly as the following tweet by the official account of UKIP: "Common sense, plain speaking, listening to voters \#WhyImVotingUkip"; finally, the qualities of the leader are important too and the German CDU campaigned to gather support for Juncker arguing that “@JunckerEU is very factual, very thoughtful and charismatic \#withjuncker”.

On the contrary, "\#EP2014 The \#FN first party in France? On May $25^{\text {th }}$ say NO to racism and YES to Europe" is a tweet written by the centrist French party Union of Democrats and

\footnotetext{
${ }^{8}$ In each country, we retained parties that won at least $2 \%$ of votes and one seat in the European Parliament, and we matched this list with the information available on their policy positions based on a expert survey (see below). Overall 33 parties have been considered (see the Appendix for details).
} 
Independents (UDI) to attack the National Front (FN) on valence issues (i.e., racism in this case, an attribute no party would like to be associated with): through messages like that UDI can perform a negative campaign against FN. ${ }^{9}$ Other examples of negative campaigning are the following: "Guess who has stolen our old slogan for its posters? The AFD!" is a tweet written by the German Free Democratic (FDP) to complain against the unfair campaigning style of Alternative for Germany (AFD). Similar complaints were quite common as many parties argued that others have stolen their proposals (for instance the right-wing Brothers of Italy attacked the PD on this point). Another quite common criticism is about non-fulfilled promises, as argued for example by the official account of the Spanish Union Progress and Democracy (UpyD): "Those in power choose a program and after the elections do not fulfill it. This produces political disaffection \#euroUPyD”. The strategy of criticizing the behavior of Members of European Parliament (MEP) was also widely used against parties such as the Northern League in Italy or the FN in France; here we report an attack moved by the Liberal Democrats in the UK: "When it comes to voting, UKIP MEPs have been exposed as the laziest in Europe. For representation vote Lib Dems". Finally, parties repeatedly criticized the campaign tone used by their opponents for being too negative, and in turn they used this as a strategy to perform negative campaigning on valence issue: for instance, the tweet "Grillo said we are like Hitler and shotguns will be used against us. He is in a tunnel. He brings in Europe the worst part of Italy", has been written by the PD to attack the M5S.

Figure 3 shows the percentage of tweets classified in each of the two categories described above as well as the total share of tweets containing a 'valence content', irrespective of its tone ('overall valence campaigning' - OVC). On the whole, 4.233 tweets expressed either a negative or a positive valence campaigning (34\% of the total number of tweets posted by parties). This value is in line with the actual share of valence messages usually broadcast on traditional media during electoral

\footnotetext{
${ }^{9}$ The content analysis of tweets was made by three trained coders. Inter-coder reliability measured on a random sample (10\% of tweets) is 0.89 (based on the average pairwise percent agreement).
} 
campaigns (e.g., Druckman et al. 2010; Gschwend et al. 2014). ${ }^{10}$ It is only slightly higher if compared to other studies that focus on Twitter and report a share of overall valence campaigning around 15-20\% both in the US 2012 Presidential election and in the 2013 Italian general election (Ceron and D'Adda, 2013; Evans et al., 2014).

When we differentiate tweets according to the tone of the valence campaigning, we observe that positive valence campaigning ( $18.5 \%$ of the total) occurs slightly more often than negative one $(15.5 \%),{ }^{11}$ albeit such difference is not statistically significant according to a simple paired t-test.

\section{Figure 3 here}

To test our hypotheses we need to assess the spatial positions adopted by parties in the 2014 European election. To do that, we take advantage of the judgments made by country's experts in a survey provided by a Voting Advice Application. ${ }^{12}$ In each country, academic experts were asked to rank the positions of parties along 21 policy issues, ranging from the economy (e.g., austerity, State

\footnotetext{
${ }^{10}$ For instance, in the 2008 US Congressional elections, Gschwend et al. (2014) reported a share of valence messages around $40 \%$ in television advertisements. Similarly, data related to recent US elections attest a share of negativity around $38 \%$ in television ads.
}

Source:http://mediaproject.wesleyan.edu/2014/09/16/dems-hold-slight-edge-in-senate-advertisingin-september-dems-lead-in-house/.

11 The higher share of PVC tweets compared to NVC tweets is in line with the results displayed in other studies based on Twitter data from the United States and the Netherlands (Evans et al., 2014; Hosh-Dayican et al., 2014).

${ }^{12}$ EU-Vox is a EU-wide voting advice application (VAA) created to monitor the match between the position of political parties and the opinions of European citizens in the 2014 European Elections (see http://www.euvox2014.eu/). 
intervention, welfare, taxes), to European affairs (e.g., Treaties, Euro, Enlargement), and social policy (immigration, law and order, abortion, gay rights). The placement of parties on each policy issue ranges from 1 (i.e., whether the party strongly agrees with the topic of the issue at stake) to 5 (i.e, whether the party strongly disagrees with the same topic). We then applied a polychoric principal component analysis to all these issues. ${ }^{13}$ The results indicate that the first two eigenvalues account for the $72 \%$ of the total variance of our 21 original variables (the first one explains the $49 \%$ of the variance, the second one the $23 \%$ ), while the third eigenvalue only accounts for an additional $7 \%$. As a consequence, we can properly collapse the original 21 items in a two dimensional policy space (coherently with our theoretical framework) and we analyze party competition therein.

Figure 4 draws the spatial position of each party included in our analysis on these two latent dimensions (the two-dimensional space of each country is reported in the Appendix). From a facevalidity view, the first (horizontal) dimension extracted appears clearly related to a left-right economic dimensions, while the second (vertical) dimensions nicely discriminates parties according to their position with respect to the European Union. These results are highly correlated with the estimates of two different external expert surveys (Benoit and Laver 2006; Steenbergen and Marks 2007). In particular, the first dimension is correlated (0.94) with the economic left-right scale and the second dimension is correlated ( 0.83$)$ with the support for a stronger European Union.

\section{Figure 4 here}

Our H1 states that the incentive of a party to highlight valence issues should grow when the distance from its neighbors decreases. This measure labeled Ideological Incentive has been estimated in the following way. Let us consider party $K$, which is surrounded by a number of adjacent (neighbors) parties within its home country: $J, Z, \ldots n$. Then:

$$
\text { Ideological Incentive }_{K}=\left\{\left[\frac{1}{d(K, J)}\right]+\left[\frac{1}{d(K, Z)}\right]+\cdots+\left[\frac{1}{d(K, n)}\right]\right\},
$$

\footnotetext{
${ }^{13}$ We ran a Polychoric Principal Component Analysis (Kolenikov and Angeles, 2004) given that the variables under investigation are not continuous.
} 
where $\mathrm{d}(\mathrm{K}, \mathrm{J})$ is the Euclidean distance between party $K$ and its neighbor party $J$, and the same holds for $d(K, Z)$ and $d(K, n)$. This measure is particularly suitable for two reasons: first, it takes into account all the possible pairs of distance separating one party from each neighbor; ${ }^{14}$ second, remember that according to (2) the functional relationship between the incentive to campaign on valence issues and the ideological considerations implies that such incentive grows more than proportionally when parties present a similar policy position. The same is true for Ideological Incentive: given Equation (3), in fact, Ideological Incentive increases exponentially for lower values of the denominators (i.e., the summation of ideological distances separating parties). We expect a positive relationship between Ideological Incentive and a party's incentive to emphasize positive and negative valence issues, even though, according to $\mathrm{H} 2$, this should be stronger for the former.

\section{Empirical results}

Our dependent variables are three fractions: respectively, the share of overall valence campaigning tweets - OVC; the share of positive valence campaigning tweets - PVC; and the share of negative valence campaigning tweets - NVC; over all tweets. We considered a fraction rather than the simple number of tweets because, by virtue of being more active on Twitter alone, parties could have different conditional propensities of posting a tweet on valence campaigning. As such we can take into account such different exposure by using the ratio. ${ }^{15}$

Given the nature of our dependent variables, which are by definition bounded between 0 and 1 , employing standard linear models may raise problems such as non-normality in the distribution of

\footnotetext{
${ }^{14}$ Note that we have computed a party's neighbors by considering only the spatial locations of parties within the same country, not across countries.

${ }^{15}$ Controlling for the number of tweets posted by each party, however, does not alter the findings. Data and scripts to replicate the analyses are available at the following URL: [withheld to protect privacy].
} 
errors (Wooldridge 2002). Thus, following Papke and Wooldridge (2008), we adopt a fractional logit model. Table 1 displays the results. Note, however, that our results hold also when we include a set of country-fixed effects to control for all other relevant aspects that are specific to each country included in our sample, or when we estimate a linear random model.

\section{Table 1 here}

Model 1 produces a clear empirical support for $\mathrm{H} 1$, that is, from the data appears to exist a spatial incentive for a party to campaign on valence issues. Moreover, this effect is far from being negligible: if we increase Ideological Incentive by one standard deviation from its mean (i.e., from 2.26 to 4.06 ), the OVC fraction is expected to increase by $33 \%$ (from .365 to .486 ).

However, contrasting the results across the three models that we estimated allows us to better fine-tuning $\mathrm{H} 1$ with respect to the tone of valence campaigning. The expected positive relationship between Ideological Incentive and valence campaigning fails to be significant at the usual 95\% level of confidence when we consider NVC (Model 2), while such relationship becomes (highly) statistically significant with respect to positive valence campaigning messages - PCV (Model 3). The different results obtained in Model 3 compared to Model 2 are coherent with H2.

Given the relatively low number of cases in our sample (33), adding further potential explanatory variables in our models would be problematic. Having said that, we tried to assess whether the impact of Ideological Incentive on valence campaigning shown in Table 1 is robust to the addition of different control variables (see also note 15).

In particular, we control for two variables related to party features that are usually deemed relevant in the existing literature: the status of a party, measured through the dummy Cabinet party to assess whether it was in office or not during the electoral campaign (Model 4 for NVC, Model 8 for PVC), and its Expected vote-share (based on the latest opinion poll released before the last week of campaign), which allows to distinguish front-runner parties from the others (Model 5 and 9). In 
addition, recent studies show that the type of the neighboring party/parties (government or opposition) can influence the occurrence of valence campaigning (Walter et al., 2014; Curini 2015): when a party is surrounded by parties of another kind (opposition parties if party $i$ is a cabinet party or vice versa), it could have more incentives to invest in valence issues. As such, in Model 6 and 10 we control for the number of neighbors different from party $i$ through the variable Opposite neighborhood. ${ }^{16}$

Finally, note that given that Ideological Incentive is summed over neighbors (see equation (3) above), it can be itself a function of the number of neighbors a political party has. This, on its turn, is a function of parties' location within the policy landscape; those at the extremes will have fewer neighbors, and therefore may have a lower value Ideological Incentive under the current formula, simply because they are in a less crowded space. We have therefore included in Model 7 and 11 the total number of neighbors a party has (that we labeled Total Neighbors) as an additional control variable, in order to confirm that the significant effect of Ideological Incentive on valence campaigning is in fact more than just a function of the number of neighbors a party has.

Table 2 displays the results. For sake of simplicity, we only report the results related to NCV and PVC even though all our findings still hold when considering OVC. This additional analysis confirms the positive and significant impact of Ideological Incentive on PVC, but not on $\mathrm{NVC}$, providing a robustness check for our theoretical framework. With respect to the control variables, being a Cabinet party reduces the amount of NVC, a result commonly found in the literature (e.g., Elmelund-Præstekær 2010), while the emphasis on PVC appears to increase when the Expected vote-share grows as well. On the contrary, both Opposite type and Total Neighbors and fail to show any substantial impact on valence campaigning, at least in our sample.

\footnotetext{
${ }^{16}$ Computing the Opposite neighborhood variable not as a raw count but as a proportion (i.e, the number of neighbors different from party $i$ over all neighbors of party $i$ ) does not change any of our results.
} 


\section{Table 2 here}

\section{Discussion}

The present paper explores the spatial determinants of valence campaigning in a twodimensional space. It presents a novel theoretical argument which is empirically tested using data from the 2014 European elections. The results provide several interesting insights to the literature on valence issues, electoral campaigning and social media more in general.

To start with, the dimensionality of the space in which parties compete matters, as the spatial theory of voting repeatedly reminds us (Banks and Austen-Smith, 2005): in a two-dimensional world a party's incentive to campaign on valence issues should grow when the ideological distance from its neighbors decreases, which is in line with the findings of previous analyses related to a one-dimensional policy space (Walter 2014; Curini 2015). When moving from one dimension to two dimensions, however, our theoretical framework suggests that the impact of ideological elements should be stronger for PVC compared to NVC and this is confirmed by our empirical findings. This happens because in a multi-dimensional space (contrary to a one-dimensional one) there is a considerable growth in the risk that a party will not internalize the entire possible electoral benefits deriving from enacting NVC, as (many) other neighbor parties will gain votes too. In a sense, and with respect to ideological considerations, multi-party competition in a two-dimensional space brings parties to "tone down" the debate as parties have more incentives to emphasize their own valence qualities rather than criticize the opponents. The empirical findings of our analysis confirm this point. Although we focused on the European elections, the breadth of our theoretical contribution is not restricted to that realm only, given that there are several national elections in which political competition takes place in a two-dimensional space (see Laver and Schofield, 1990).

This result, however, does not imply that we would not observe negative valence campaigning in a two-dimensional world. In fact, there can be other reasons (beyond ideological considerations) why, even in such environment, parties decide to go negative. This may happen, for 
instance, if parties do not focus on the short term only but take into account the outcome of future events (other elections or post-election bargaining), or if they act to signal to voters for which party they should not vote at all, in order to prevent the growth and the success of rival parties (rather than to maximize their own share), or, finally, if they want to take advantage of scandals affecting other parties (Kumlin and Esaiasson 2012). This consideration, however, lies beyond the scope of our work.

Finally, the political science literature has recently devoted increasing attention to the potential role played by social media data in testing theories (e.g., Clark and Golder 2015, Nagler and Tucker 2015, Bond and Messing 2015, Barbera 2015). By taking advantage of an original comparative dataset on the campaign strategies of political parties measured through the content of parties official Twitter accounts, the present paper also contributes to this debate. This measurement could be fruitfully extended to systematically monitor additional countries, parties and elections. This would provide a novel (and precious) source of information on political issues that complements more conventional sources of data such as the advertisements broadcast on traditional media, or mass-surveys, which have been widely used in the literature on electoral campaigns.

Our results suggest also several ways to improve the theoretical model here discussed. First, while policy stance is taken in (1) and (2) to fall within a multi-dimensional space, valence is defined to be a single independent dimension. This decision simplifies our model and makes it easier to test, but it also denies two possibilities: first, that valence issues may be multidimensional in the same way as policy issues, and second, that valence issues may interact in some way with policy issues. Future research might consider incorporating both of these possibilities. Similarly, we have calculated ideological incentive in such a way that the distances between a party and all of its neighbors are all taken to have an equal weight (a by-product of our assumption of a uniform distribution of voters). Still, the incentives to compete on valence issues could be greater for parties located in positions with a greater density of voters. Future research should also consider incorporating a larger time frame, more countries, and more policy 
dimensions in order to further validate the relationship between spatial and valence considerations here discussed. Similarly, distinguishing the specific target of valence campaigning (for example, towards which party the negative attack is directed at) could be an additional way to refine our theoretical argument.

\section{References}

Abney, R., Adams, J., Clark, M., Easton, M., Ezrow, L., Kosmidis, S., and Neundorf, A. (2013). When does valence matter? Heightened valence effects for governing parties during election campaigns. Party Politics, 19, 61-82.

Adams, J.F., S. Merill, and B. Grofman (2005) A Unified Theory of Party Competition. A Cross-National Analysis Integrating Spatial and Behavioral Factors, Cambridge: Cambridge University Press.

Adams, J., Merrill, S., Simas, E., Stone, W. (2011). When Candidates Value Good Character: A Spatial Model with Applications to Congressional Elections. Journal of Politics. 73 (1): $17-30$

Ansolabehere, S. and J.M. Snyder (2000). 'Valence politics and equilibrium in spatial election models', Public Choice 103, pp.327-336.

Ashworth, S. and E. Bueno de Mesquita (2009). Elections with platform and valence competition. Games and Economic Behavior. 67(1), 191-216.

Austen-Smith, David and Jeffrey S. Banks (2005). Positive Political Theory II. Strategy and Structure, Ann Arbor: University of Michigan Press.

Barbera, Pablo (2015). Birds of the Same Feather Tweet Together: Bayesian Ideal Point Estimation Using Twitter Data, Political Analysis, 23(1), 76-91.

Benoit, Kenneth, and Michael Laver. (2006). Party Policy in Modern Democracies, London: Routledge. 
Bond, Robert, and Solomon Messing (2015). Quantifying Social Media's Political Space: Estimating Ideology from Publicly Revealed Preferences on Facebook, American Political Science Review, 109(1), 62-78

Budge, I. and Farlie D. J. (1983) Explaining and Predicting Elections: Issue Effects and Party Strategies in Twenty-Three Democracies. London: Allen \& Unwin.

Budge, Ian, Klingemann, H.-D., Volkens, A., Bara, J. and Tanenbaum, E. (2001). Mapping Policy Preferences: Estimates for Parties, Electors, and Governments 1945-1998, Oxford: Oxford University Press.

Calvo, E., and T. Hellwig (2011) 'Centripetal and Centrifugal Incentives under Different Electoral Systems', American Journal of Political Science, 55, 1: 27-41.

Ceron, A. and G. D'Adda (2013). E-campaigning on Twitter: The effectiveness of distributive promises and negative campaign in the 2013 Italian election. New Media and Society, DOI: $10.1177 / 1461444815571915$

Clark, M. (2013). Does Public Opinion Respond to Shifts in Party Valence? A CrossNational Analysis of Western Europe, 1976-2002. West European Politics, 37(1): 91-112.

Clark, William Roberts and Matt Golder (2015). Big Data, Causal Inference, and Formal Theory: Contradictory Trends in Political Science? - Introduction, PS: Political Science and Politics, 48 (01), $65-70$

Cox, Gary W. 1990. "Centripetal and Centrifugal Incentives in Electoral Systems." American Journal of Political Science 34 (4): 903-35.

Curini, L. (2015). The Conditional Ideological Inducement to Campaign on Character Valence Issues in Multiparty Systems The Case of Corruption. Comparative Political Studies, 48(2): 168-192

Curini, L., and Martelli, P. (2010). Ideological proximity and valence competition. Negative campaigning through allegation of corruption in the Italian legislative arena from 1946 to 1994. Electoral Studies, 29(4), 636-647. 
Curini, L. and Martelli, P. (2015) 'A case of valence competition in elections: Parties' emphasis on corruption in electoral manifestos', Party Politics, vol. 21, no. 5, pp. 686-698.

Damore, D. F. (2002). Candidate Strategy and the Decision to Go Negative. Political Research Quarterly, 55(3), 669-686.

Druckman, J. N., Kifer, M. J., and Parkin, M. (2010). Timeless Strategy Meets New Medium: Going Negative on Congressional Campaign Web Sites, 2002-2006, Political Communication, 27(1), 88-103.

Elmelund-Præstekær, Christina (2008). Negative campaigning in a multiparty system, Representation, 44: 27-39.

Elmelund-Præstekær, C., 2010. Beyond American negativity: toward a general understanding of the determinants of negative campaigning. European Political Science Review 2 (1), 137-156.

Elmer, G. (2013). Live research: Twittering an election debate. New Media and Society, 15(1), 18-30.

Enns, Peter K., and Brian Richman (2013). Presidential Campaigns and the Fundamentals Reconsidered'. Journal of Politics 75(03): 803-20.

Evans HK, Cordova V and Sipole S (2014) Twitter Style: An Analysis of How House Candidates Used Twitter in Their 2012 Campaigns. PS: Political Science and Politics, 47(2): 454462.

Green, J. (2007). When voters and parties agree: Valence issues and party competition. Political Studies 55(3): 629-655.

Groseclose T. (2001), A Model of Candidate Location When One Candidate Has a Valence Advantage, American Journal of Political Science, Vol.45, n.4, 862-886

Gschwend, Thomas, Lukas Stoetzer and Steffen Zittlau (2014). 'Why don’t you talk about policy? Valence campaigning in the 2008 US Congressional elections'. Paper presented for the $4^{\text {th }}$ EPSA Conference, Edinburgh, 19-21 June 2014. 
Hallin, Daniel C., and Paolo Mancini (2004). Comparing Media Systems: Three Models of Media and Politics, Cambridge University Press: Cambridge

Hansen, K.M. and R.T. Pedersen (2008), Negative campaigning in a multiparty system, Scandinavian Political Studies, 31(4), pp.408-427

Hix, Simon, and Michael Marsh (2011). 'Second-Order Effects plus Pan-European Political Swings: An Analysis of European Parliament Elections across Time'. Electoral Studies 30(1): 415.

Hix, Simon, Abdul Noury, and Gérard Roland (2007). Democratic Politics in the European Parliament. Cambridge University Press.

Hosh-Dayican, Bengü, Amrit, Chintan, Aarts, Kees, and Dassen, Adrie (2014). How Do Online Citizens Persuade Fellow Voters? Using Twitter During the 2012 Dutch Parliamentary Election Campaign. Social Science Computer Review, doi: 10.1177/0894439314558200.

Kolenikov, Stanislav and Gustavo Angeles (2004). The Use of Discrete Data in PCA: Theory, Simulations, and Applications to Socioeconomic Indices. Working paper WP-04-85, MEASURE/Evaluation project, Carolina Population Center, University of North Carolina, Chapel Hill

Kumlin, S. and Esaiasson, P. (2012). Scandal fatigue? Scandal elections and satisfaction with democracy in Western Europe, 1977-2007. British Journal of Political Science 42: 263-282

Laver, M. and Hunt, W.B. (1992). Policy and Party Competition. London: Routledge.

Laver M. and Schofield, N. (1990). Multiparty Governments: The Politics of Coalition in Europe. Oxford: Oxford University Press.

Laver, Michael and Ernest Sergenti (2012). Party competition: an agent-based model. Princeton: Princeton University Press

McDonald, M., \& Budge, I. (2005). Elections, parties, and democracy: Conferring the median mandate. Oxford: Oxford University Press. 
McGann, A. J. (2002). 'The Advantages of Ideological Cohesion A Model of Constituency Representation and Electoral Competition in Multi-Party Democracies'. Journal of Theoretical Politics 14(1): 37-70.

Meirowitz, Adam (2008). "Electoral Contests, Incumbency Advantages, and Campaign Finance”. Journal of Politics 70(3): 681-699.

Nagler, Jonathan and Joshua A. Tucker (2015). Drawing Inferences and Testing Theories with Big Data, PS: Political Science and Politics, 48 (01): 84 - 88

Okabe, Atsuyuki, Barry Boots, Kokichi Sugihara, and Sung Now Chiu (2000). Spatial Tessellations: Concepts and Applications of Voronoi Diagrams. New York: John Wiley

Papke, L.E., and Wooldridge, J.M. (2008). Panel data methods for fractional response variables with an application to test pass rates. Journal of Econometrics, 145, 121-133.

Reif, Karlheinz, and Hermann Schmitt (1980). 'Nine Second-Order National Elections - a Conceptual Framework for the Analysis of European Election Results'. European Journal of Political Research 8(1): 3-44

Schofield N. (2003), "Valence Competition in the Spatial Stochastic Model", Journal of Theoretical Politics, 15(4): 371-383

Schofield, Norman., and Itai Sened (2006). Multiparty Democracy: Parties, Elections and Legislative Politics in Multiparty Systems. Cambridge: Cambridge University Press.

Serra, Gilles (2010), Polarization of what? A Model of Elections with Endogenous Valence, Journal of Politics, 72 (2): 426-437

Shikano, Susumu and Konstantin Käppner (2014). Exploiting feeling thermometer scores: A simultaneous estimation of ideological space and valence factors, Paper presented at the annual meeting of the Midwest Political Science Association, Chicago, April 3-6

Skaperdas Stergios and Bernard Grofman (1995). 'Modelling Negative Campaigning', American Political Science Review, 89, pp.49-61 
Snyder, James M., Jr., and Michael M. Ting (2002). 'An Informational Rationale for Political Parties'. American Journal of Political Science 46(1): 90-110.

Steenbergen, Marco and Gary Marks. (2007). Evaluating Expert Judgments. European Journal of Political Research 46(3): 347-366

Stokes, Donald E. (1963). Spatial Models of Party Competition. The American Political Science Review 57 (2): 368-77.Stone, W. J., \& Simas, E. N. (2010). Candidate valence and ideological positions in U.S. House Elections. American Journal of Political Science, 54, 371-388.

Vergeer, M, and Hermans, L. (2013). Campaigning on Twitter. Micro-blogging and online social networking as campaign tools in the 2010 general elections in the Netherlands. Journal of Computer-Mediated Communication, 18(4), 399-419

Vergeer, M, Hermans, L, and Sams, S. (2013). Online social networks and micro-blogging in political campaigning: The exploration of a new campaign tool and a new campaign style. Party Politics, 19(3), 477-501

Walter, A. S. (2014) Choosing the Enemy: Attack Behaviour in a Multiparty System, Party Politics, 20(3): 311-323

Walter, A. S., W. van der Brug and P. van Praag (2014) When the Stakes are High: Party Competition and Negative Campaigning, Comparative Political Studies, 47 (4), 550-573

Williams, Laron K. (2015). It's all relative: Spatial position of parties and ideological shifts, European Journal of Political Research, 54: 141-159

Wlezien, Christopher, and Robert S. Erikson (2002). 'The Timeline of Presidential Election Campaigns'. Journal of Politics 64(4): 969-93.

Wooldridge, J.M. (2002). Econometric Analysis of Cross Section and Panel Data. Boston: MIT Press.Zakharov, A. V. (2009). A model of candidate location with endogenous valence. Public Choice, 138, 347-366. 
Zakharova, Maria and Paul Warwick. (2014) The Sources of Valence Judgments: The Role of Policy Distance and the Structure of the Left-Right Spectrum. Comparative Political Studies, 47(14): 2000-2025

\section{Tables}

Table 1. Explaining the share of OVC, NVC and PVC (fractional logit estimates)

\begin{tabular}{lccc}
\hline & Model 1: OVC & Model 2: NVC & Model 3: PVC \\
\hline - Ideological Incentive & $0.277^{* *}$ & 0.188 & $0.183^{* * *}$ \\
& $(0.125)$ & $(0.107)$ & $(0.0479)$ \\
Constant & $-1.177^{* * *}$ & $-2.064^{* * *}$ & $-1.835^{* * *}$ \\
& $(0.286)$ & $(0.290)$ & $(0.223)$ \\
\hline Observations & 33 & 33 & 33 \\
Log pseudolikelihood & -14.88 & -10.52 & -11.32 \\
\hline \multicolumn{2}{c}{ Robust standard errors in parentheses; ${ }^{*} p<0.05,{ }^{* *} p<0.01,{ }^{* * *} p<0.001$}
\end{tabular}

Table 2. Explaining the share PVC: robustness check (fractional logit estimates)

\begin{tabular}{|c|c|c|c|c|c|c|c|c|}
\hline & $\begin{array}{l}\text { Model 4: } \\
\text { NVC }\end{array}$ & $\begin{array}{l}\text { Model 5: } \\
\text { NVC }\end{array}$ & $\begin{array}{l}\text { Model 6: } \\
\text { NVC }\end{array}$ & $\begin{array}{c}\text { Model 7: } \\
\text { NVC }\end{array}$ & $\begin{array}{l}\text { Model 8: } \\
\text { PVC }\end{array}$ & $\begin{array}{l}\text { Model 9: } \\
\text { PVC }\end{array}$ & $\begin{array}{l}\text { Model 10: } \\
\text { PVC }\end{array}$ & $\begin{array}{l}\text { Model 11: } \\
\text { PVC }\end{array}$ \\
\hline - Ideological Incentive & $\begin{array}{c}0.157 \\
(0.105)\end{array}$ & $\begin{array}{c}0.177 \\
(0.104)\end{array}$ & $\begin{array}{c}0.181 \\
(0.102)\end{array}$ & $\begin{array}{c}0.188 \\
(0.112)\end{array}$ & $\begin{array}{l}0.191^{* * *} \\
(0.0520)\end{array}$ & $\begin{array}{l}0.216^{* * * *} \\
(0.0523)\end{array}$ & $\begin{array}{l}0.193^{* * * *} \\
(0.0569)\end{array}$ & $\begin{array}{c}0.172^{* * *} \\
(0.0554)\end{array}$ \\
\hline - Cabinet party & $\begin{array}{l}-0.991^{* *} \\
(0.349)\end{array}$ & - & - & - & $\begin{array}{c}0.200 \\
(0.333)\end{array}$ & - & - & - \\
\hline - Expected vote-share & - & $\begin{array}{c}-1.085 \\
(1.496)\end{array}$ & - & - & - & $\begin{array}{c}2.568^{*} \\
(1.313)\end{array}$ & - & - \\
\hline - Opposite type & - & - & $\begin{array}{c}-0.0445 \\
(0.122)\end{array}$ & - & - & - & $\begin{array}{c}0.0654 \\
(0.138)\end{array}$ & - \\
\hline - Total Neighbors & - & - & - & $\begin{array}{c}-0.00111 \\
(0.144)\end{array}$ & - & - & - & $\begin{array}{c}0.116 \\
(0.128)\end{array}$ \\
\hline Constant & $\begin{array}{c}-1.800^{* * *} \\
(0.308)\end{array}$ & $\begin{array}{c}-1.896^{* * *} \\
(0.348)\end{array}$ & $\begin{array}{c}-1.999^{* * *} \\
(0.276)\end{array}$ & $\begin{array}{c}-2.061^{* * *} \\
(0.446)\end{array}$ & $\begin{array}{c}-1.908^{* * *} \\
(0.271)\end{array}$ & $\begin{array}{c}-2.283^{* * *} \\
(0.304)\end{array}$ & $\begin{array}{c}-1.932^{* * *} \\
(0.332)\end{array}$ & $\begin{array}{c}-2.179^{* * *} \\
(0.505)\end{array}$ \\
\hline Observations & 33 & 33 & 33 & 33 & 33 & 33 & 33 & 33 \\
\hline Log pseudolikelihood & -10.22 & -10.49 & -10.52 & -10.52 & -11.30 & -11.14 & -11.31 & -11.29 \\
\hline
\end{tabular}




\section{Figures}

Figure 1. The two-dimensional Italian policy space for the 2014 European Election

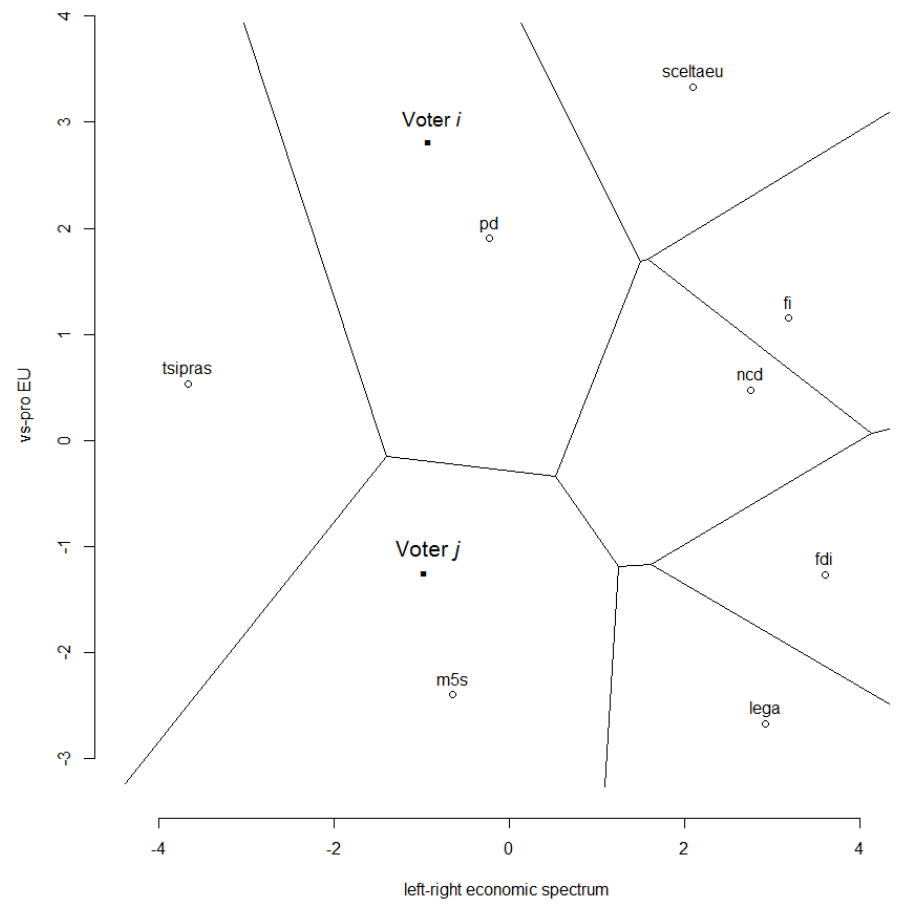

Legenda : fdi $=$ Brothers of Italy; $\mathrm{pd}=$ Democratic Party; sceltaeu $=$ European Choice; fi $=$ Forward Italy; tsipras $=$ Tsipras List $/$ The other Europe with Tsipras; $\mathrm{m} 5 \mathrm{~s}=$ Movement 5 Stars; ncd $=$ New center-Right; lega $=$ Northern League

Figure 2. A two-party system in which party $K$ displays the same valence advantage: party $J$ and $K$ far away from each other (left panel) or closer to each other (right panel)
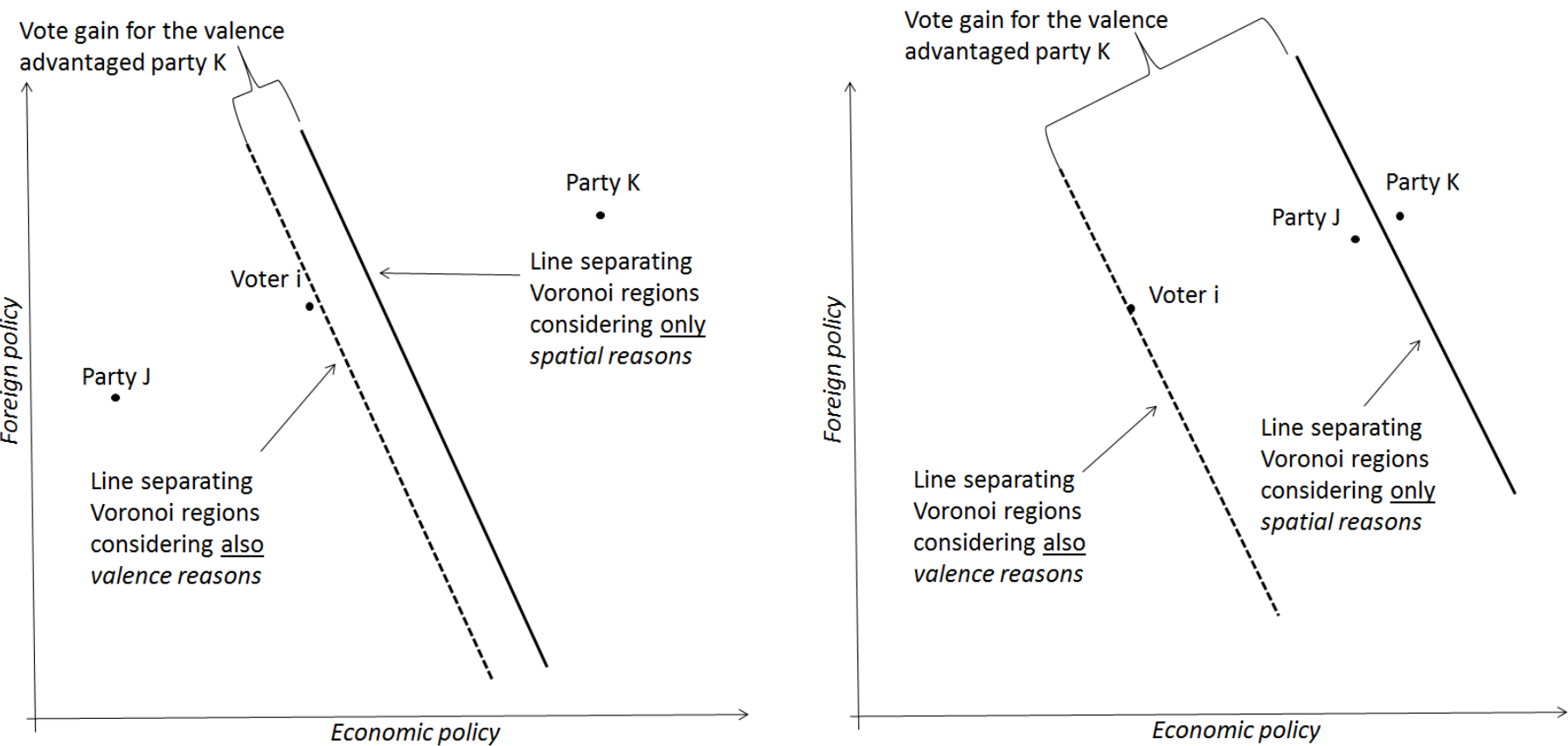
Figure 3. Share of NVC, $P V C$ and $O V C$ tweets

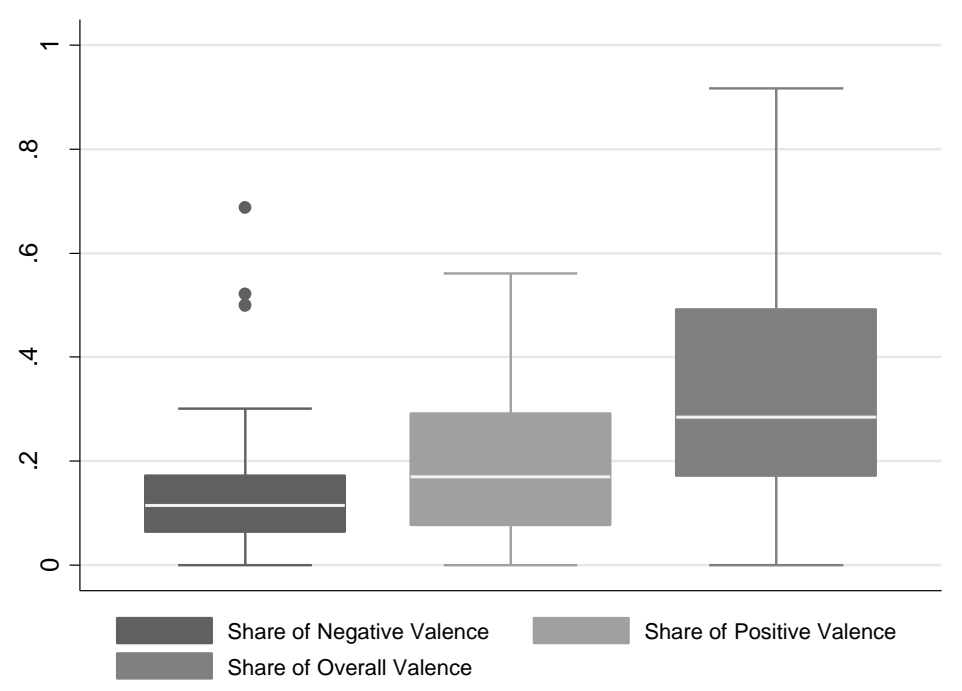

Figure 4. The spatial position of parties concurring in the 2014 European Elections

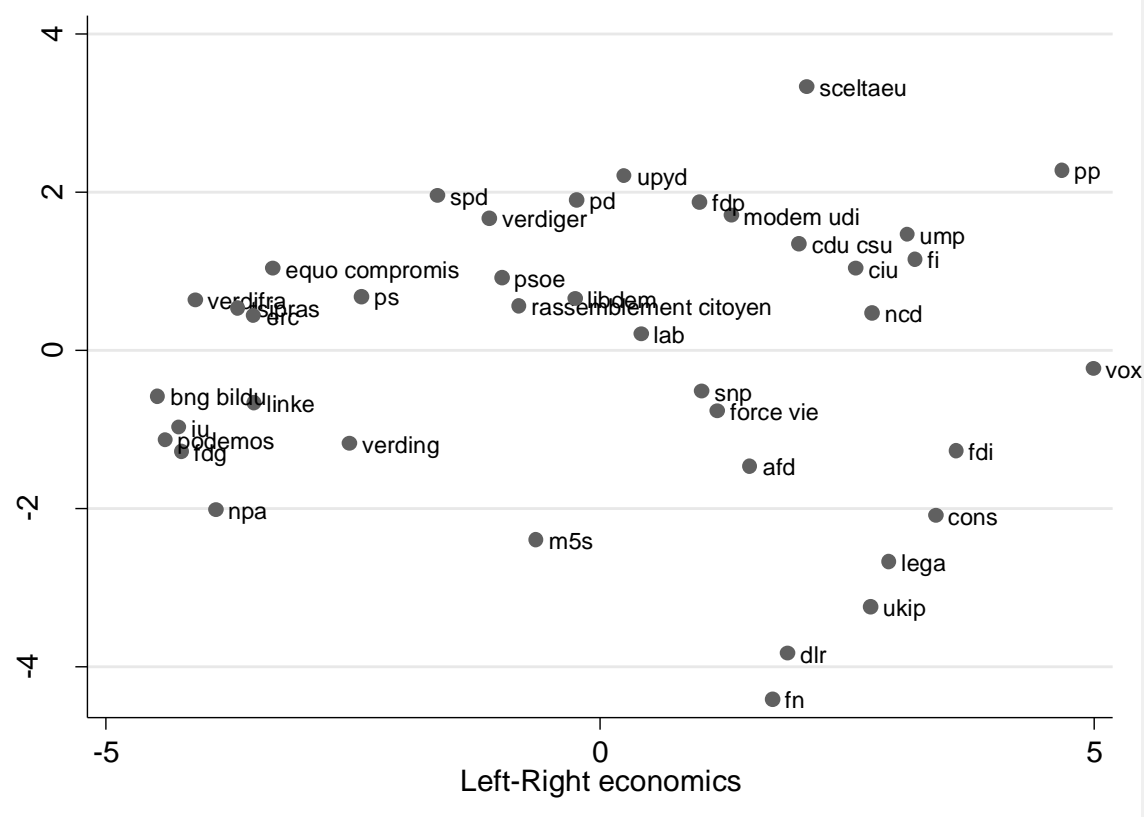




\section{Appendix}

Table 1A. List of parties and Twitter accounts, number of tweets downloaded and date of Election

\begin{tabular}{|c|c|c|c|c|}
\hline Party & Twitter account & $\begin{array}{l}\text { Published } \\
\text { Tweets }\end{array}$ & Country & $\begin{array}{l}\text { Election } \\
\text { day }\end{array}$ \\
\hline Arise the Republic & http://twitter.com/DLR_Officiel & 138 & France & 25 May \\
\hline $\begin{array}{l}\text { Democratic Movement and the Union } \\
\text { of Democrats and Independents }\end{array}$ & http://twitter.com/MoDem & 868 & France & 25 May \\
\hline Left front & http://twitter.com/FDG & 32 & France & 25 May \\
\hline National Front & http://twitter.com/FN_officiel & 32 & France & 25 May \\
\hline Socialist Party & http://twitter.com/partisocialiste & 575 & France & 25 May \\
\hline The Greens & http://twitter.com/eelv & 1250 & France & 25 May \\
\hline Union for a Popular Movement & http://twitter.com/ump & 116 & France & 25 May \\
\hline Alternative for Germany & https://twitter.com/afd_bund & 28 & Germany & 25 May \\
\hline Christian Democratic Union & http://twitter.com/CDU & 887 & Germany & 25 May \\
\hline Free Democratic Party & http://twitter.com/fdp_de & 120 & Germany & 25 May \\
\hline Social Democratic Party of Germany & http://twitter.com/spdde & 101 & Germany & 25 May \\
\hline The Greens/Alliance 90 & http://twitter.com/die_gruenen & 155 & Germany & 25 May \\
\hline The Left & http://twitter.com/dielinke & 76 & Germany & 25 May \\
\hline Brothers of Italy & http://twitter.com/FratellidItalia & 268 & Italy & 25 May \\
\hline Democratic Party & http://twitter.com/pdnetwork & 246 & Italy & 25 May \\
\hline European Choice & http://twitter.com/SceltaEu & 40 & Italy & 25 May \\
\hline Forward Italy & http://twitter.com/forza_italia & 1406 & Italy & 25 May \\
\hline Tsipras List & http://twitter.com/altraeuropa & 299 & Italy & 25 May \\
\hline Movement 5 Stars & http://twitter.com/Mov5Stelle & 585 & Italy & 25 May \\
\hline New Center-Right & http://twitter.com/NCD_tweet & 511 & Italy & 25 May \\
\hline Northern League & http://twitter.com/LegaNordPadania & 575 & Italy & 25 May \\
\hline People's Party & http://twitter.com/PPopular & 178 & Spain & 25 May \\
\hline Spanish Socialist Workers' Party & http://twitter.com/Psoe & 827 & Spain & 25 May \\
\hline Union Progress and Democracy & http://twitter.com/upyd & 642 & Spain & 25 May \\
\hline United Left & http://twitter.com/iunida & 87 & Spain & 25 May \\
\hline Coalition for Europe & $\begin{array}{l}\text { http://twitter.com/convergenciacat } \\
\text { http://twitter.com/unio_cat } \\
\text { http://twitter.com/eajpnv_eu }\end{array}$ & 37 & Spain & 25 May \\
\hline We can & http://twitter.com/ahorapodemos & 24 & Spain & 25 May \\
\hline Conservative Party & http://twitter.com/Conservatives & 41 & UK & 22 May \\
\hline Labour Party & http://twitter.com/UKLabour & 239 & UK & 22 May \\
\hline Liberal Democrats & http://twitter.com/LibDems & 571 & UK & 22 May \\
\hline Scottish National Party & http://twitter.com/theSNP & 234 & UK & 22 May \\
\hline The Greens & http://twitter.com/TheGreenParty & 332 & UK & 22 May \\
\hline UK Indipendence Party & http://twitter.com/UKIP & 941 & UK & 22 May \\
\hline Total & & 12,461 & & \\
\hline
\end{tabular}


Figure 1A. The two-dimensional policy space for the 2014 European Election:

Germany, UK, France and Spain
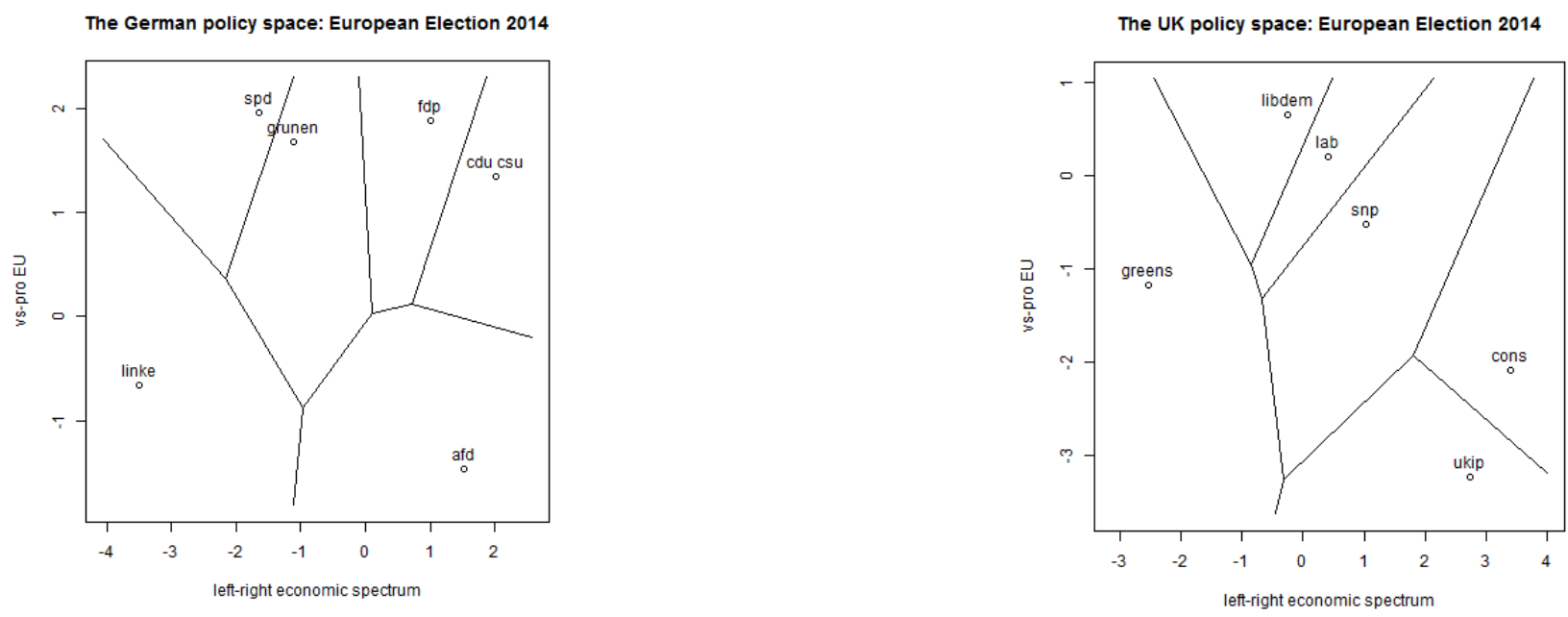

The French policy space: European Election 2014

The Spanish policy space: European Election 2014
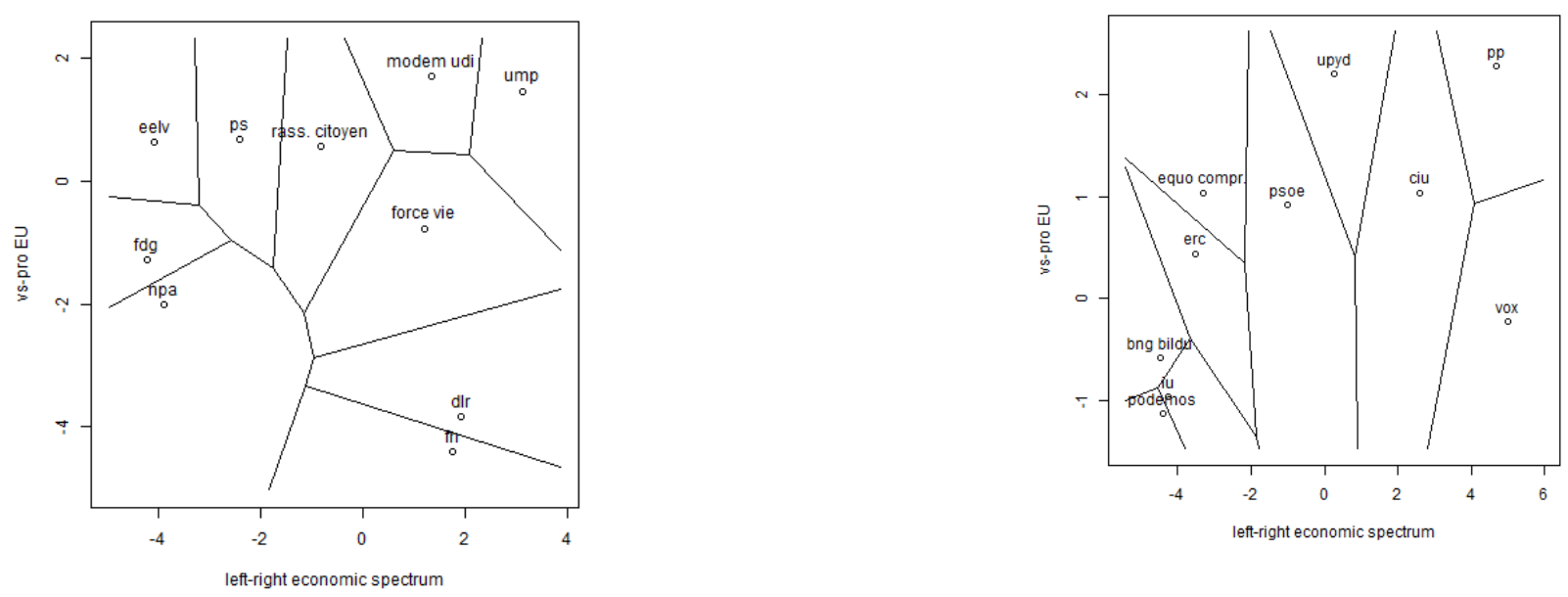